\title{
Islamic Banking Products: Regulations, Issues and Challenges
}

\author{
Nooraslinda Abdul Aris, Universiti Teknologi MARA, Malaysia \\ Rohana Othman, Universiti Teknologi MARA, Malaysia \\ Rafidah Mohd Azli, Universiti Teknologi MARA, Malaysia \\ Mardiyyah Sahri, Universiti Teknologi MARA, Malaysia \\ Dzuljastri Abdul Razak, International Islamic University. Malaysia \\ Zaharuddin Abdul Rahman, International Islamic University. Malaysia
}

\begin{abstract}
The Islamic world is in its evolutionary phase. Islamic finance which comprises the banking system, takaful (Islamic insurance) and capital market products and services offer an alternative to society. The development is said to be phenomenal with a double-digit annual growth rate since its inception. McKinsey \& Company (2007) in his study stated that the value of Islamic banking assets and assets under Islamic management is expected to reach USD1 trillion by 2010, with Islamic banks growing more rapidly than the average banking sector in most countries. As of 2009, worldwide assets under shari'ah compliance grew four times from $0.5 \%$ to $2 \%$ of the world economy and reached MYR3.5 trillion (PEMANDU, 2010). With the increasing trends of Islamic finance, Islamic financial institutions (IFIs) around the world are encouraged to develop and innovate new products in order to meet the ever-changing demand from its customers and potential customers. The introduction of new Islamic products does impose some challenges, not only to the practitioners and Shari'ah council members, but also to society at large, as they are the ultimate users of the product. This paper aims to look at the development and regulations of new Islamic banking products with focus given more on Islamic house financing. Such developments bring about variation in the products introduced to the public as different contracts are adopted. The focus will be mainly on IFIs operating and regulated in Malaysia with specific enforcement by the country's regulators.
\end{abstract}

Keywords: Islamic Finance; Islamic House Financing; Product Development; Regulation

\section{INTRODUCTION}

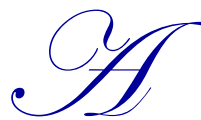

s written by Hesse, Jobst, \& Sole (2008), the rapid evolution of Islamic finance activities has allowed profit opportunities for financial institutions. This has in fact prompted a vetting process among world jurisdictions to establish themselves as the leading Islamic financial center. It is mentioned that London has made the most remarkable effort in becoming a world Islamic financial center and this is followed by Hong Kong, New York and Singapore. In this particular case, Kuala Lumpur and Dubai are being considered as more established Islamic centers. Singapore is interested in becoming one of the Islamic centers for two main reasons: (i) neighboring Malaysia and Indonesia have successfully introduced Islamic banking into their financial services sector and (ii) to compete for Muslim sourced deposits on an equal basis available throughout South East Asia (Gerrard \& Cunningham, 1997).

Hesse, Jobst, \& Sole (2008) were of the opinion that Islamic finance has established itself as a permanent element within the global financial landscape. The permissibility of risky capital investment without explicit interest earning has merged the three basic forms of Islamic financing, namely (i) synthetic loans which are debt-based through sales and repurchase agreements; (ii) lease contracts based on assets through sales and leaseback agreements (operating lease) or third-party acquired assets with purchase obligations (finance lease); and (iii) profit sharing contracts which is equity based for future assets. 
Islamic finance rests on the general idea of extending the tenets of Islamic religious belief to economic activity in one way or another that enhances social welfare. Islamic contracts are normally asset-based and it must comply with Shari'ah, which prohibits riba' (excess interest), gharar (uncertainty), maisir (gambling) and other non-halal activities. The prohibition of riba', gharar and maisir as mentioned in the Qur'an and hadith must be strictly followed by the financial institutions. The contract between the financiers and borrowers are governed by shared business risk and returns from entrepreneurial investment. This basically differs from the conventional whereby the relationship is normally based on capital-based investment gains arising from the time value of money.

Shari'ah is the Islamic law of human conduct, which governs business matters. Because of the probation of certain elements in transactions, Islamic banks have to develop financial products that conform to shari'ah. This may result in having a mirror product that the conventional has already in their pipeline. It involves the accountability and responsibility of all the key functions (board of directors, Shari'ah committee and management) for an IFI to implement the Shari'ah Governance Framework, which was introduced in late 2010 by the Central Bank of Malaysia. Taking for example the deposit product of savings accounts in conventional banks which are based on interest, whereby an Islamic bank will have the same product named as savings account $i$ ( $i$ denotes Islamic in Malaysia's case) which is under the contract of either wadiah (safe keeping) or mudharabah (profit sharing). This is said to satisfy the shari'ah and at the same time the customers' needs. Restyling the existing product has created a number of special products in the market (Ali \& Ali, 1994). With these new innovative products, the relationship between financiers and borrowers are considered a partnership in which risk is attached instead of being borne by a single party. Products are said to be categorized into four major contracts i.e. ijarah (leasing), mudharabah (profit sharing), musharakah (partnership) and murabahah (deferred payment sale).

As Islamic banks have increased its presence and position around the globe via Islamic windows and/or offering specific Islamic financial products or in acting as fully-fledged Islamic licenced banks, the two important issues to look at are the legal aspects of the Islamic contract and the regulatory aspects of IFIs. Recognising and realising the fact that society has now been given an alternative way of doing banking, the paper examines the dual banking system available to Muslims and society. In addition, the development and regulations of Islamic banking products are identified here, with special focus given to Islamic house financing.

\section{ISLAMIC BANKING AND MAQASID SHARI'AH}

In discussing Islamic banking one must first explore its roots, which can be found in maqasid shari'ah, which is arguably the foundation of Islamic banking. In Arabic, the term maqasid means goals, or purposes (Wikipedia contributors, 2010). Therefore, in relation to this, when one talks about maqasid shari'ah, one basically refers to the goals or purposes of Islamic law. "Maqasid of the Islamic law highlights rationales, purposes and common good in the Islamic rulings and stresses their importance, while basing itself on the Islamic scripts and observing the Islamic faith" (Al-Shaikh-Ali \& Auda, 2006).

Many scholars have agreed that the ultimate objective of maqasid shari'ah is to serve the interests of humankind and to protect them from harm. However, others have defined maqasid shari'ah in different ways.

Al-Ghazali (1973) has described it as the importance of preserving the well-being of the people through the safeguarding of their faith (din), their lives (nafs), their intellect ('aql), their posterity (nasl), and their wealth (mal), while at the same time highlighting that these five points, when fulfilled adequately, serve public interest and is therefore desirable. However, whatever is done not in accordance with these five points is against public interest and should therefore be removed.

While at the same time, Imam al-Shatibi (1884) defines maqasid shari'ah from a more epistemological perspective, inferring that the aim of shari'ah is to free man from selfish endeavors in order for him to realize his place in the scheme of things and serve God willingly and wholeheartedly.

Ibn Ashur (2006) explains that the maqasid, in promoting the well-being and virtue of man, also preserves, in consequence, the social order of the community and its healthy progress. He points out that virtue can be fulfilled through thinking intelligently and doing good deeds, as well as utilizing all the gifts that God has bestowed on him, in a righteous manner that may benefit society as a whole. 
Supporting the idea of an all-encompassing guide to a well-ordered and fulfilling human civilization, Ahmad al-Raysuni (2005) has defined the overall objective of maqasid as the preservation of an ordered and peaceful society wherein the people placed there on earth, act as its responsible caretakers, as God had placed them there as His vicegerents. As such, using all the resources at his disposal, they must therefore live justly and promote moral propriety and integrity, in thought and action, for the benefit of all.

There are basically four main characteristics of maqasid shari'ah. Firstly, maqasid shari'ah is the foundation of legislation, with the purpose to act in the benefit of all human beings, preserving them from harm. Secondly, they are universal, as their objectives, in trying to serve the needs and interests of all, include all mankind and require their total obedience and acceptance. Next, they are inclusive or absolute, encompassing all human acts irrespective of whether they relate to the responsibilities of God ('ibadah) or to the responsibilities of other human beings (mu'amalah). Lastly, maqasid shari'ah is definitive, as they have been taken from many different sources, and not just from one single text or item of evidence (Dusuki \& Bouheraoua, 2011).

It is a precept of Islam that maqasid shari'ah should be observed in its entirety and not partially, as Islam encompasses all patterns of life and its purpose does not just address both the personal and public sides of life, but also the one in the Hereafter (Ibn Ashur, 2006 and Kamali, 1998). Maslahah or public interest is at the heart of maqasid shari'ah itself, and as such, the general objective of Shari'ah lays in preserving the order of society and ensuring its steady and healthy progress. Since finance plays a big role in modern everyday life, it is not unreasonable to argue that the harmony of society depends quite frequently on financial matters. Islam recognizes this, classifying the protection and preservation of wealth in the category of essential matters (daruriyyat), exemplifying the recognition of finance by the maqasid shari'ah as a valuable aspect of life (Vejzagic \& Smolo, 2011).

The maqasid shari'ah can be seen as a guide for IFIs to comply with the standards of virtue and moral consciousness that have been advocated by the Shari'ah (Dusuki \& Bouheraoua, 2011), which expects a balance, upheld by firms, in relation to the rights and responsibilities of the individual and of society (Chapra, 1992). As such, the many prohibitions established by the Shari'ah should be treated with the aim of providing a level playing field in order to protect the interests of everyone involved as well as create the harmonious society that has been envisioned by the maqasid shari'ah. One could argue that the maqasid shari'ah provide, especially for financial institutions, a framework for decision-making and a means to adapt to change. Furthermore, they act as guidelines for moral judgment (Dusuki \& Bouheraoua, 2011).

Islamic banking, arguably the most important sector of Islamic finance, refers to a banking system whose principles, in relation to its operations and activities are based on Islamic rules. That is, all the operations carried out by the Islamic bank, all its transactions must be based on the principles set forth by the Shari'ah. The fundamental difference between Islamic and conventional banks is that all the transactions made by Islamic banks are implemented without involving elements of riba', which is strictly prohibited in Islam. The principle aim of Islamic banks is to cater to the needs of Muslims in banking transactions and providing alternatives to the rest. These banks are founded on rulings based on the Qur'an and the Hadith, and their management is based on the Islamic precepts of justice and fairness in the interests of society (Haron \& Wan Azmi, 2009). Other factor influenced by Shari'ah are the Ijma (agreement or a consensus among Muslim jurists) and the Qiyas (analogical reasoning to clear about a particular case). Muslim jurists extend a former ruling to a new case using analogies between the present case and the former one. It explained further about Qur'an and Hadith to make it easily understood by the layman (Nakagawa, 2009).

Islamic banks are a quite recent phenomena compared to the history of conventional banks, which scholars have dated to have come about nearly 420 years ago in Venice (Homoud, 1985). The history of modern Islamic banking can be traced back to the establishment of the Mit Ghamr Savings Bank in Egypt in 1963, which functioned on the basis of Shari'ah principles. This was a turning point in banking everywhere, especially to the Muslim world, as the success of this bank proved that Shari'ah principles were valid and applicable to modern-day business. As a consequence, since then many Islamic banks have been established worldwide, and not only in Islamic countries. According to the International Monetary Fund, at the end of 2007, there were more than 300 financial institutions in 75 countries operating in accordance with Shari'ah regulations. Islamic banking activities are also not limited solely 
to Islamic banks. Many conventional banks have adopted Islamic banking techniques and instruments, as well as offer banking products, based on Shari'ah principles to cater to the needs of their Muslim clients as well as those of the Islamic banks they do business with.

However, the sole consideration of conventional banks in all its activities is still profit. Islamic banks on the other hand, are founded not only profit, but on religion as well. As they are founded on the religion of Islam, they must comply with its principles, putting more importance on moral values. However, at the same time, they are expected to make profit from their business dealings. It is a balancing act that Islamic banks must try to consolidate in order to succeed. In its business objectives, they must find equilibrium between profit and religion, because in achieving one aspect and not the other, the bank is defeating the whole purpose of its existence. In being a success profit-wise, yet by neglecting the norms of Shari'ah compliance, the bank is a failure as an Islamic institution. Inversely, focusing solely on Islamic law and disregarding the profit-making aspects of the bank's dealings would mean its failure as a business institution, leading to bankruptcy and the inability to continue on. Therefore, a healthy balance between both of its key features, profit and religion, is crucial to the success and survival of the bank as an IFI.

There are three categories in which Islamic banking institutions may be categorized. The first, are ordinary financial institutions offering Islamic banking products and services, which are not prohibited in Islam, but do not adhere to other business principles as required by Islam. In the second category are IFIs that are banking businesses, which classify financial institutions which regard themselves as IFIs, but in reality, the products and services they offer are similar to ordinary financial institutions. While the third, IFIs offering Islamic banking products and services, are generally considered the best choice, as not only do they offer Islamic banking, but all their business operations are founded on Islamic business principles (Haron \& Wan Azmi, 2009). The Malaysian government also allowed conventional banking institutions to begin Islamic banking at the early stage in 1993. However, the global crisis in 1997 affected the number of conventional banks offering Islamic banking services due to the restructuring program of the Central Bank (Nakagawa, 2009).

Malaysia is a unique and diverse country that has a dual banking system, in which conventional and Islamic banking operate on a parallel basis and walk hand in hand. The advantage of this dual system to consumers and businesses is the opportunity to enjoy the flexibility of selecting the benefits from both of the banking systems. A question normally raised by customers is: "What are the differences between conventional and Islamic banking products?"

From an Islamic perspective, there are haram elements (riba', gharar and maisir) in the conventional financial system, in which the product or service is exchanged without the price known ex-ante to all parties in the transactions. This uncertainty exists in conventional systems, which are incompliant with the Shari'ah and hence may lead to higher risks.

Unlike conventional bank accounts, deposits into an Islamic bank account using the contract of wadiah or mudharabah do not receive interest. The depositors' money is kept and invested in a legal and shari'ah way. The profit is then allocated between the banks and its depositors proportionately as both parties are considered partners. In this manner, the banks act as the depositors' agent, dispersing funds on their behalf to worthy customers.

Under a financing facility, in which customers wish to own a house, the bank will buy the property identified by the customer and resell it to the customer at a mark-up amount. The selling price is said to have the profit element allowable under shari'ah and therefore is recognized as profit to the bank. The customer will then pay the financing at mark-up value in a period that is stated and agreed upon. Notwithstanding, the bank is allowed to charge or impose a compensation fee should the customer fail to pay when it is due. However, the penalty imposed to the customer is minimal (1\% on installment amount) and non-compounding, as Islam promotes the principle of truth, fairness, and justice.

In Malaysia, there are seventeen local and foreign banks registered and operating on an Islamic base, such as Bank Islam Malaysia Berhad, Bank Muamalat Malaysia Berhad, Maybank Islamic Berhad, AmIslamic Bank Berhad, CIMB Islamic Bank Berhad, HSBC Amanah Malaysia Berhad, Standard Chartered Saadiq Berhad, Al-Rajhi Banking \& Investment Corporation (Malaysia) Berhad and Kuwait Finance House (Malaysia) Berhad. 
For a clearer understanding on the differences between Islamic banks and conventional banks, Table 1 below provides a summary of the subject matter:

Table 1: The differences between conventional and Islamic banks

\begin{tabular}{|c|c|c|}
\hline & CONVENTIONAL BANKS & ISLAMIC BANKS \\
\hline Functions and operating modes & Fully based on man-made principles. & Must be based on Shari'ah principles. \\
\hline Investor assurance & Predetermined rate of interest. & $\begin{array}{l}\text { Investor as capital provider and management } \\
\text { as entrepreneur share the risk, hence profit } \\
\text { rates are only indicators. }\end{array}$ \\
\hline Aims & $\begin{array}{l}\text { Maximizing profit without any } \\
\text { restrictions. }\end{array}$ & $\begin{array}{l}\text { Maximizing profit subject to shari'ah } \\
\text { restrictions. }\end{array}$ \\
\hline Rules of accounts & $\begin{array}{l}\text { Governed by product terms and } \\
\text { conditions. }\end{array}$ & $\begin{array}{l}\text { Governed by undertaking contracts, } \\
\text { determining the terms and conditions. }\end{array}$ \\
\hline Fundamental function & $\begin{array}{l}\text { Lending and borrowing with } \\
\text { compounding interest. }\end{array}$ & $\begin{array}{l}\text { Participation in partnership business. } \\
\text { Important to understand the customers' } \\
\text { business. }\end{array}$ \\
\hline Relationship & Creditors and debtors. & $\begin{array}{l}\text { Could be: } \\
\text { - Partners, } \\
\text { - Investors and traders, } \\
\text { - Buyers and sellers. }\end{array}$ \\
\hline Deposits rate and guarantee & $\begin{array}{l}\text { Fixed interest rates and deposits are fully } \\
\text { guaranteed. }\end{array}$ & $\begin{array}{l}\text { Non-guaranteed return may be given as hibah } \\
\text { (gift) and rate of return must be indicative rate. } \\
\text { Only wadiah deposit accounts are guaranteed. }\end{array}$ \\
\hline Loan / financing rate & $\begin{array}{l}\text { Usually based on floating rates, BLR +/- } \\
\text { rates. }\end{array}$ & $\begin{array}{l}\text { - Fixed profit mark-up (Bai Bithamin Ajil, } \\
\text { Murabahah) } \\
\text { - Floating profit rates (Musharakah, Ijarah) }\end{array}$ \\
\hline
\end{tabular}

\section{ISLAMIC BANKING PRODUCT DEVELOPMENT}

Most Islamic products are introduced as an alternative to conventional products. Looking at the ever changing and dynamic environment, Islamic banks need to innovate and create new products in order to remain competitive. The products must be attractive and appealing to individual and corporate clients. Not only that, but the advancement of technology and the evolution of financial markets demand that new products/services be introduced on a timely basis.

El-Galfy and Khiyar (2012) addressed the challenges faced by economic development policy makers to encourage risk-sharing instead of debt-financing. As a result, it will reduce poverty and inequality in order to achieve better socio-economic development and bring greater justice to the society as a whole. Therefore, an Islamic banking and financial system can be served as an instrument to endorse economic growth and benefit humankind since it positively contributes to macroeconomic stability.

The banking sectors can be categorized into individual and corporate, which require different products to fulfill their needs. Unlike the conventional banking system, Islamic banks and their clients are partners (Bujang Masli, 2010); whereby both sides of the financial intermediation are based on sharing risks and gains. The transfer of funds from client to the bank (depositing) is based on revenue sharing and usually calculated ex post on a monthly basis, while the transfer of funds from the bank to the clients is based on profit sharing (financing) either at a mutually agreed-upon ratio as in the case of mudharabah or at a mutually agreed-upon fixed rate (Imady \& Siebel, 2006). Such ratios (revenue and profit sharing) and rates vary between institutions and may also vary between contracts within the same institutions, contingent upon perceived business prospects and risk.

Islamic banking products are recognized based on the contracts instead of the commercial orientation. The current Islamic banking products can be categorized as shown in Table 2 below: 
Table 2: Islamic Banking products offered by Islamic banks in Malaysia by business segment

\begin{tabular}{|c|c|c|}
\hline CONSUMER SEGMENT & PRODUCT NAME & CONTRACT USED \\
\hline \multirow[t]{2}{*}{ Deposit } & $\begin{array}{l}\text { Current account } \\
\text { Saving account }\end{array}$ & $\begin{array}{l}\text { - Wadiah (safe keeping) } \\
\text { - Mudharabah (profit sharing) }\end{array}$ \\
\hline & Staff deposit account & Qard Hassan (benevolent) \\
\hline Credit & Credit card & Tawarruq (cost plus sale) \\
\hline \multirow[t]{4}{*}{ Financing } & House financing & $\begin{array}{l}\text { - } \quad \text { Bai Bithaman Ajil - BBA (deferred payment sale) } \\
\text { - } \quad \text { Musharakah Mutanaqisah (diminishing partnership) }\end{array}$ \\
\hline & Personal financing & $\begin{array}{l}\text { - } \quad \text { Murabahah (cost plus) } \\
\text { - } \quad \text { BBA (deferred payment sale) } \\
\text { - } \quad \text { Bai Inah (immediate cash) } \\
\end{array}$ \\
\hline & Vehicle financing & - $\quad$ BBA (deferred payment sale) \\
\hline & Staff financing & Qard Hassan (benevolent) \\
\hline \multirow[t]{4}{*}{ CORPORATE SEGMENT } & PRODUCT TYPE & CONTRACT USED \\
\hline & Trade financing & $\begin{array}{l}\text { - } \quad \text { Wakalah (agency) } \\
\text { - } \quad \text { Mudharabah (profit sharing) } \\
\text { - } \quad \text { Murabahah (cost plus) } \\
\end{array}$ \\
\hline & Asset based financing & $\begin{array}{l}\text { - Ijarah (leasing), } \\
\text { - Istisna (purchase order) }\end{array}$ \\
\hline & Corporate investment & $\begin{array}{l}\text { - } \quad \text { BBA (deferred payment) } \\
\text { - } \quad \text { Ijarah (leasing) } \\
\text { - } \quad \text { Istisna (purchase order) } \\
\text { - } \text { Murabahah (cost plus) } \\
\text { - Mudharabah (profit sharing) } \\
\text { - Musharakah (profit and loss sharing) }\end{array}$ \\
\hline
\end{tabular}

The banking sector in Malaysia was developed together with the economy of the country and may be influenced by the world economy. In order to fulfill the requirements of the consumer, individual and corporate, the financial institutions come up with new innovative products in order to remain competitive. This is also seen as a way to allow greater flexibility in the industry to cope with the dynamic environment.

The guidelines on the introduction of new products by BNM in 2007 defined new product as " $a$ product that is being offered by the financial institution in Malaysia for the first time or a combination of or variation to an existing product that results in a material change to the risk profile of the existing product". The definition would assist the financial institution in defining the new product intended to be introduced to the public. It is the duty of the Chief Risk Officer (CRO) or other designated senior risk officer identified by the financial institutions to determine whether a variation of an existing product constitutes a material change, which considers the risk implications from both the perspectives of the financial providers and the customers. The basis of risk determination must be documented and readily available for review.

Notwithstanding, BNM also indicates that the new product must also have the element of consumer protection to ensure that risk is managed properly for the sake of justice for all. This is in line with the Islamic teaching that IFIs should be built based on a societal foundation or upon religious principles that may help institutions introduce products designed and price-based on the principle of societal equality (Kwon, 2007), brotherhood and solidarity (Imady \& Siebel, 2006).

In order to compete with each other, these IFIs tend to introduce new products in the market to enhance their credibility and also to boost their market share. As new products become increasingly innovative, complex in nature and diverse in response to consumer demand, there is a potential misinterpretation of maqasid shari'ah of the contracts, laws or even the principle used. Hence, new products for Islamic banking institutions must adhere to the shari'ah as per the guidelines of BNM. One of the initial requirements to submit new products for approval is that the product must be endorsed by the IFIs Shari'ah Advisory Board (SAB). Shari'ah members appointed by the financial institution must first and foremost be recognized by BNM. This is to justify that only those qualified can advise on the compliance of a product to the shari'ah principles. 
The guidelines introduced by BNM aim to improve the time-to-market for financial institutions to introduce new products, or to effect changes to existing products; promote sound risk management practices in managing and controlling product risk by ensuring the appropriate assessment and mitigation of risk during the product development and marketing stages; and further strengthen the duty of care owed to consumers in ensuring that products developed and marketed are appropriate to the needs, resources and financial capability of targeted consumer segments.

\section{ISLAMIC PRODUCT VARIATIONS - HOUSE FINANCING}

Financing products can be classified depending on the Islamic contract such as mudharabah, murabahah, musharakah, Bai' Bithaman Ajil (BBA), ijarah, wakalah and/or Qard Hassan. For deposit products, the contracts normally used are wadiah and mudharabah. All these products must be approved by BNM prior to its introduction. However, it is acknowledged that variations exist in Islamic banking products although the names may be similar. This is due to the fact that the Islamic bank's SAB may have a different interpretation of the contracts, principles, and jurist and scholar views used in defending the product applicability and compliance to the shari'ah as guided by BNM. This also includes the variation in the rates, ratios, terms and other benefits.

To prove that such variation exists, let's look and compare the house financing products under the contract of BBA of Bank Islam, Maybank Islamic and Standard Chartered Saadiq and also the new contract adopted, called Musharakah Mutanaqisah (MM) by RHB Islamic, HSBC Amanah and Kuwait Finance House.

Table 3: Comparison of house financing products based on the BBA contract between three established Islamic banks in Malaysia

\begin{tabular}{|c|c|c|c|}
\hline \multicolumn{4}{|c|}{ 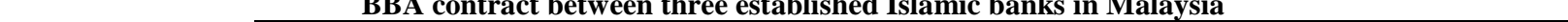 } \\
\hline & $\begin{array}{c}\text { Bank Islam } \\
\text { Malaysia Berhad } \\
\end{array}$ & $\begin{array}{c}\text { Maybank Islamic } \\
\text { Berhad }\end{array}$ & $\begin{array}{c}\text { Standard Chartered } \\
\text { Saadiq Berhad }\end{array}$ \\
\hline Product & Baiti Home Financing-i & Home Financing-i & $\begin{array}{ll}\text { - } & \text { JustHome-i } \\
\text { - } & \text { Saadiq My Home-i } \\
\end{array}$ \\
\hline Contract & BBA & BBA & BBA \\
\hline Rates & Competitive financing rates & Fixed rate financing & $\begin{array}{l}\text { Variable rate financing with a } \\
\text { fixed ceiling rate }\end{array}$ \\
\hline $\begin{array}{l}\text { Margin of } \\
\text { financing }\end{array}$ & $\begin{array}{l}\text { Up to } 90 \% \text { including takaful } \\
\text { contribution }\end{array}$ & $\begin{array}{l}\text { Up to } 100 \% \text { with mortgage/home } \\
\text { building takaful }\end{array}$ & Up to $90 \%$ \\
\hline Financing tenure & $\begin{array}{l}\text { Up to } 40 \text { years or age } 65, \\
\text { whichever earlier }\end{array}$ & Up to 10 years & $\mathrm{n} / \mathrm{a}$ \\
\hline Scope & $\begin{array}{l}\text { Property under construction and } \\
\text { completed properties }\end{array}$ & $\begin{array}{l}\text { Property under construction and } \\
\text { completed properties }\end{array}$ & $\begin{array}{l}\text { Property under construction and } \\
\text { completed properties }\end{array}$ \\
\hline $\begin{array}{l}\text { Benefits } \\
\text { highlighted }\end{array}$ & $\begin{array}{l}\text { - Selling price is known } \\
\text { - Easy for future plan } \\
\text { - Early settlement is entitled } \\
\text { for rebates } \\
\text { - Payment can be either fixed } \\
\text { or step-up monthly } \\
\text { installment }\end{array}$ & $\begin{array}{l}\text { - } \quad \text { No capitalization of profit } \\
\text { - } \quad \text { Third party financing is } \\
\text { allowed } \\
\text { - } \quad \text { Granting of rebate for early } \\
\text { settlement } \\
\text { - No security deposit }\end{array}$ & $\begin{array}{l}\text { - } \text { Based on Shari'ah principles } \\
\text { - Buy and sell concept which } \\
\text { includes a profit margin } \\
\text { agreed by both parties } \\
\text { - Available to all }\end{array}$ \\
\hline
\end{tabular}

(Sources: website of Bank Islam, Maybank Islamic and Standard Chartered Saadiq) 
Table 4: Comparison of house financing product based on the

\begin{tabular}{|c|c|c|c|}
\hline \multicolumn{4}{|c|}{ MM contract between three establish Islamic financial institutions in Malaysia } \\
\hline & $\begin{array}{l}\text { RHB Islamic } \\
\text { Bank Berhad }\end{array}$ & $\begin{array}{c}\text { HSBC Amanah } \\
\text { Malaysia Berhad }\end{array}$ & $\begin{array}{c}\text { Kuwait Finance House } \\
\text { (Malaysia) Berhad }\end{array}$ \\
\hline Product & $\begin{array}{l}\text { Equity Home } \\
\text { Financing-i }\end{array}$ & HomeSmart-i & $\begin{array}{l}\text { Musharakah Mutanaqisah Home } \\
\text { Financing-i }\end{array}$ \\
\hline Contract & MM / Diminishing Partnership & MM / Diminishing Partnership & MM with Ijarah \\
\hline Rates & Variable rate financing & Variable rate financing & $\begin{array}{l}\text { Multi-tiered based on } \\
\text { prevailing rates }\end{array}$ \\
\hline $\begin{array}{l}\text { Margin of } \\
\text { advance }\end{array}$ & $\begin{array}{l}\text { Up to } 100 \% \text { including takaful } \\
\text { contribution }\end{array}$ & Up to $90 \%$ & Up to $90 \%$ \\
\hline Financing tenure & $\mathrm{n} / \mathrm{a}$ & $\begin{array}{l}\text { Up to } 35 \text { years or until age } 65 \\
\text { whichever is earlier }\end{array}$ & $\begin{array}{l}\text { Up to } 35 \text { years or age } 70 \\
\text { whichever is earlier }\end{array}$ \\
\hline Scope & $\begin{array}{l}\text { Completed and under } \\
\text { construction properties }\end{array}$ & $\begin{array}{l}\text { Completed and under } \\
\text { construction properties and } \\
\text { refinancing }\end{array}$ & Selective property project \\
\hline $\begin{array}{l}\text { Benefits } \\
\text { highlighted }\end{array}$ & $\begin{array}{ll}\text { - } & \text { Flexible payment plans } \\
\text { - } & \text { Longer Musharakah tenure } \\
\text { - } & \text { Available and convenience } \\
\text { of payment methods at more } \\
\text { than } 180 \text { RHB Banks \& } \\
\text { RHB Islamic Bank branches }\end{array}$ & $\begin{array}{l}\text { Freedom to make } \\
\text { prepayments and withdrawals } \\
\text { on excess payments anytime } \\
\text { without notice or charges. } \\
\text { - Stamp duty waiver on } \\
\text { financing documents on new } \\
\text { home purchases and } \\
\text { refinancing from existing } \\
\text { conventional home loan. }\end{array}$ & $\begin{array}{ll} & \text { Equity partnership } \\
- & \text { Value-for-money financing } \\
\text { packages with greater } \\
\text { flexibility } \\
\text { - Enjoy financing of MRTT } \\
\text { Takaful at a reasonable } \\
\text { profit rate. } \\
\text { - Competitive Shari'ah } \\
\text { compliant MRTT packages } \\
\text { that protects your } \\
\text { investment } \\
\text { Open for Malaysian and non- } \\
\text { Resident }\end{array}$ \\
\hline
\end{tabular}

(Sources: website of RHB Bank, HSBC Amanah and Kuwait Finance House)

Based on the two tables shown above and our observations, it is proven that a house financing product under the same contract (either BBA or MM) may have variances in terms of names, rates, the margin of financing, scope, tenure and takaful coverage even the benefits highlighted. Thus, creating a complex environment for the Islamic finance industry and posing a greater task for regulators to monitor the product compliance in the country.

\section{LEGISLATIONS AND REGULATIONS}

Central Bank of Malaysia (known as Bank Negara Malaysia or BNM) and the Security Commission (SC) regulate all registered financial institutions in Malaysia. Both regulators play important roles in ensuring the compliance and adherence to the laws, acts and guidelines. These are crucial as a control mechanism and to monitor the performance of the IFIs. Currently all IFIs are regulated by BNM under the purview of the Islamic Banking and Takaful Division.

Bank Negara Malaysia was established on 26 January 1959 under the Central Bank of Malaysia Act (CBMA 1958). The Act has been repealed by Central Bank of Malaysia Act 2009 (effective 25 November 2009). The roles and functions of the Central Bank are varied, and important to the stability of Malaysia's economy. Among the major functions of BNM is the prudent conduct of monetary policy the implementation of stability in the financial system, the fostering of the development of the financial sector, the developmental role played to ensure the existence of a good financial infrastructure and the promotion of financial inclusion for the country. Their governance includes all financial institutions that consist of commercial banks, finance companies, merchant banks, Islamic banks, leasing companies, and development finance institutions (BNM, 1999).

As of 31 December 2011 there are 65 registered financial institutions (both conventional and Islamic) listed under the BNM purview with 24 commercial banks, 17 Islamic banks, 4 international Islamic banks, 15 investments banks and 6 money brokers. 
IFI is the term used to describe all financial institutions that operate in line with shari'ah requirements. Generally, in order to be considered an IFI, there must be a Shari'ah board comprise of more than one scholar qualified to issue an opinion on the shari'ah compliance of a financial product and also the operation of the institutions. There are conflicting statistics about the size and total number of Islamic financial institutions globally, but the International Financial Services London, a financial industry trade group in the U.K. estimates that as of the end of 2007, there were 280 Islamic financial institutions globally with total assets of USD729 billion (IFSL Research, 2009).

To enable BNM to meet the objectives of a central bank, it is vested with comprehensive legal powers under the Banking and Financial Institutions Act 1989 (BAFIA), Islamic Banking Act 1983 and Takaful Act 1984 to regulate and supervise the financial system. Some of these legal powers are manifested in legislation such as: the Central Bank of Malaysia Act 2009, which provides for the continued existence of the Central Bank of Malaysia in carrying out its duties; the Banking and Financial Institutions Act 1989 (BAFIA), which provides new laws for the licensing and regulation of institutions that include banking, finance companies, merchant banking, discount houses and money-broking businesses for the regulation of institutions involved in financial business; the Islamic Banking Act 1983, which provides for the licensing and regulation of Islamic banking business; the Takaful Act 1984, which provides for the regulation of takaful business in Malaysia and for other purposes relating to or connected with takaful; the Development Financial Institutions Act 2002 (Act 618) or DFIA, which focuses on promoting the development of effective and efficient development financial institutions (DFIs) to ensure that their roles, objectives and activities are consistent with Government policies and that the mandated roles are effectively and efficiently implemented, also providing a comprehensive supervision mechanism to strengthen the financial position of DFIs through the specification of prudential requirements; and the Money Services Business Act 2011, which provides for the licensing, regulation and supervision of money services business and to provide for related matters (BNM, 2012). Along with that, BNM also has listed guidelines and circulars for IFIs in order to ensure that they work in harmony with the country's financial system and so that close monitoring could be done.

The Shari'ah Advisory Council (SAC) of BNM was established in May 1997 as the highest Shari'ah authority in Islamic finance in Malaysia. The SAC has been given the authority for the ascertainment of Islamic law for the purposes of Islamic banking business, takaful business; Islamic financial business, Islamic development financial business, or any other business based on Shari'ah principles and supervised and regulated by BNM. As the reference body and advisor to BNM on Shari'ah matters, the SAC is also responsible for validating all Islamic banking and takaful products to ensure their compatibility with the Shari'ah principles. In addition, it advises BNM on any Shari'ah issue relating to Islamic financial business or transactions of BNM as well as other related entities. Their role and function was further reinforced in the recent Central Bank of Malaysia Act (CBMA) 2009.

While the rulings of the SAC prevail over any contradictory ruling given by a Shari'ah body or committee constituted in Malaysia, the court and arbitrator are also required to refer to the rulings of the SAC for any proceedings relating to Islamic financial business. Such rulings are also binding. The SAC consists of prominent Shari'ah scholars, jurists and market practitioners who are qualified and have vast experience in banking, finance, economics, law and the application of Shari'ah, especially in terms of Islamic economics and finance (BNM, 2012).

\section{CONCLUSION}

Islamic finance and IFIs are getting well known with a proven good track record since its introduction to society. The growing number of assets and assets management under the classification "Islamic" is evidence of the level of acceptance by the market. To compete on a level playing field with other financial institutions, Islamic banks would need to be competitive and this means producing and having more innovative products that meet the demands of the individual and businesses. The Islamic products developed must comply not only with shari'ah requirements but also with the country's legislation, guidelines and circulars.

The products and services offered by Islamic banks is an alternative to conventional banking. As highlighted, there are differences between these two banking systems and consumers have the rights to know and choose which bank to use. Hence, there should be a medium available to the public to inform them on banking products and services and their features and benefits, in order to allow them to choose the bank that best meets their 
needs and demands. Since Islam promotes fairness, justice and transparency, banks should observe these ideals as well.

Product development must follow the guidelines and adhere to shari'ah prior to its introduction. Islamic banking products need to be endorsed by the internal shari'ah supervisory board. The variations in products, which have the same contract, may be due to different interpretations by the shari'ah advisors.

Although standardization is claimed to be good as it allows for comparison, it is time that consumers are given some variation in their banking products. Therefore, the consumer will need to appreciate and understand the specialty of every Islamic product in each Islamic bank. Islamic house financing based on the contract of BBA and MM is a good example in which the same financing product is available using two different contracts. This enables society to choose from a variety of choices, as long it does not contradict shari'ah.

Corporate governance, supervision and monitoring the operations and performance of the Islamic banks are crucial in ensuring that banks carry the role to serve their client the shari'ah way. Without proper regulations, policies and enforcement, the implication is normally transferred to the consumer.

\section{ACKNOWLEDGMENT}

This article would not have been possible without the support of many organizations. The authors wish to express their gratitude to the Ministry of Higher Education (MOHE) and Accounting Research Institute, University Teknologi MARA (UiTM) for providing the financial means and facilities.

\section{AUTHOR INFORMATION}

Nooraslinda Abdul Aris is currently a lecturer in Faculty of Accountancy of Universiti Teknologi MARA (UiTM) Malaysia. She obtained her MBA from International Islamic University Malaysia (IIUM) and professional qualification (ACCA) from MARA Polytech College, Kuala Lumpur. Prior to joining UiTM, she worked in the industry, namely with Standard Chartered Bank, Syarikat Takaful Malaysia, Atracc Sdn Bhd (Shell Shared Service centre) and Caltex Oil Berhad. Noraslinda is a member of the Association of Chartered Certified Accountants (ACCA) and Malaysian Institute of Accountants (MIA). E-mail: nooraslinda@salam.uitm.edu.my (Corresponding author)

Prof. Dr. Rohana Othman is a Professor in Accounting at the Faculty of Accountancy, Universiti Teknologi MARA, Malaysia. She received her Doctorate in Accounting from the International Islamic University Malaysia (IIUM). She also holds a Bachelor of Science (BSc) in Accounting from Indiana State University, United States of America (USA) and a Master in Business Administration (specializing in Accounting) from University of Hartford, Connecticut, USA. Her current research interests include Islamic Finance, Earnings Management and Creative Accounting, Public Sector Accountability and Governance, Corporate Governance and Corporate Social Responsibility. E-mail: rohana799@salam.uitm.edu.my

Rafidah Mohd Azli is currently a lecturer in Centre of Islamic Thought and Understanding of Universiti Teknologi MARA (UiTM) Malaysia. She obtained her MAIRK (Master of Islamic Revealed Knowledge) from the International Islamic University Malaysia (IIUM). Currently she is an associate fellow of Institut Kajian Zakat, UiTM.

Mardhiyyah Sahri is currently a lecturer in the Centre for Islamic Thought and Understanding of Universiti Teknologi MARA (UiTM) Malaysia. She obtained her Master of Comparative Law (MCL) from the International Islamic University Malaysia (IIUM). Prior to joining UiTM, she worked with the Centre for Foundation Studies, International Islamic University Malaysia as a law lecturer. 


\section{REFERENCES}

1. Al-Ghazali, A. H. (1973). al-Mustasfa min 'Ilm al-Usul. Cairo: al-Maktabah al-Tijariyyah.

2. Ali, S. N., \& Ali, N. N. (1994). Information Sources on Islamic Banking and Economics: 1980-1990. London: Kegan Paul International.

3. Al-Qurtubi, A. '. (n.d.). Tafseer al-Qurtubi. Beirut: Daar lhyaa al-Turaath al-Arabi.

4. Al-Raysuni, A. (2005). Imam Al-Shatibi's Theory of the Higher Objectives and Intents of Islamic Law. London and Washington: International Institute of Islamic Thought.

5. Al-Shaikh-Ali, A. S., \& Auda, G. (2006). Foreword. En M. A.-T. Ibn Ashur, Treatise on Maqasid alShari'ah (págs. ix-xi). London and Washington: International Institute of Islamic Thought.

6. Al-Shatibi, A. I. (1884). al-Muwafaqat, Edited by Salih al-Qa'iji and others. Tunis: Matba'a Dawlatiyya.

7. BNM. (2012). Administered Legislation. Bank Negara Malaysia:

http://www.bnm.gov.my/index.php?ch=14

8. $\quad$ BNM. (2012). References. Bank Negara Malaysia: http://www.bnm.gov.my/index.php?ch=18\&pg $=55 \& \mathrm{ac}=584$

9. $\quad$ BNM. (2012). Shariah Advisory Council of the Bank. Bank Negara Malaysia: http://www.bnm.gov.my/index.php?ch=7\&pg=715\&ac=802

10. BNM. (1999). The Central Bank and the Financial System in Malaysia: A Decade of Change 1989-1999. Kuala Lumpur: Bank Negara Malaysia.

11. Bujang Masli, A. L. (2010). Presentation on Accounting Treatment for Islamic Banking Products. Kuala Lumpur: Islamic Banking and Finance Institute Malaysia Sdn. Bhd.

12. Chapra, M. U. (1992). Islam and the Economic Challenge. Leicester: The Islamic Foundation.

13. Dusuki, A. W., \& Bouheraoua, S. (2011). The Framework of Maqasid Al-Shari'ah (Objectives of the Shari'ah) and its Implications for Islamic Finance. Kuala Lumpur: International Institute of Advanced Islamic Studies.

14. El-Galfy, A. \& Khiyar, K. A. (2012). Islamic Banking and Econimic Growth: A Review. The Journal of Applied Business Research-September/October 2012, Volume 28(5), pp. 943-956.

15. Gerrard, P., \& Cunningham, J. B. (1997). Islamic Banking: A Study in Singapore. International Journal of Bank Marketing , 204-216.

16. Haron, S., \& Wan Azmi, W. N. (2009). Islamic Finance and Banking System: Philosophies, Principles and Practices. Shah Alam: McGraw-Hill.

17. Hesse, H., Jobst, A. A., \& Solé, J. (2008). Trends and Challenges in Islamic Finance. World Economics Vol. 9 No. 2 , 175-193.

18. Homoud, S. H. (1985). Islamic Banking. London: Arabian Information Ltd.

19. Ibn Ashur, M. T. (2006). Treatise on Maqasid al-Shari'ah. London and Washington: International Institute of Islamic Thought.

20. IFSL Research. (2009). Islamic Finance 2009. London: International Financial Services London.

21. Imady, O., \& Siebel, H. D. (2006). Principles and Products of Islamic Finance. University of Cologne Development Research Center.

22. ISRA. (2011). Islamic Financial System: Principles and Operations. Kuala Lumpur: International Shari'ah Research Academy for Islamic Finance.

23. Kamali, M. H. (1998). Al-Maqasid Al-Shari'ah: THe Objectives of Islamic Law. The Muslim Lawyer, 3(1) , $1-7$.

24. Kwon, W. J. (2007). Islamic Principles and Takaful Insurance: Re-evaluation. Journal of Insurance Regulation Vol. 26 Issue 1.

25. McKinsey \& Company. (2007). The World Islamic Banking Competitiveness Report 2007-2008: Capturing the Trillion Dollar Opportunity.

26. Nakagawa, R. (2009). The Evolution Of Islamic Finance In Southest Asia: The Case Of Malaysia. The Journal of Applied Business Research- January/ February 2009, Volume 25 (1), pp. 111-126.

27. Nyazee, I. A. (2000). Islamic Jurisprudence (Usul al-Fiqh). Islamabad: Islamic Research Institute Press.

28. PEMANDU. (2010). Malaysian Economic Transformation Programme. Putrajaya: Malaysian Government, Chapter 7 Financial Services. 
29. Vejzagic, M., \& Smolo, E. (2011). Maqasid al-Shari'ah in Islamic Finance: An Overview. 4th Islamic Economic System Conference (pág. 22). Kuala Lumpur: Faculty of Economics and Muamalat and Islamic Finance and Wealth Management Institute, Universiti Sains Malaysia.

30. Wikipedia contributors. (29 de 12 de 2010). Maqasid. Recuperado el 31 de 01 de 2012, de Wikipedia, The Free Encyclopedia : http://en.wikipedia.org/w/index.php?title=Maqasid\&oldid=404833998

31. Yusuf Ali, A. (2008). The Holy Qur'an: Original Arabic Text with English Translation \& Selected Commentaries. Kuala Lumpur: Saba Islamic Media.

\section{BIBLIOGRAPHY}

1. Al Rajhi Bank (Malaysia) website www.alrajhibank.com.my

2. Bank Islam Malaysia Berhad website www.bankislam.com.my

3. Bank Negara Malaysia website www.bnm.gov.my

4. Banking and Financial Institutions Act (BAFIA) 1989

5. Central Bank of Malaysia Act (CBMA) 2009

6. HSBC Amanah Malaysia Berhad website www.hsbc.com.my

7. Islamic Banking Act (IBA) 1983

8. Kuwait Finance House (M) Berhad website www.kfh.com.my

9. Maybank Islamic Berhad website www.maybank2u.com.my

10. Standard Chartered Saadiq Berhad website www.standardcharted.com.my/islamic-banking 